\title{
İSLÂMÎ BİREYIN VE TOPLUMUN OLUŞMASINDA KUR'ÂN'I ANLAMA/YAŞAMA SORUNU: DERÛNÎ VE YÜZEYSEL OKUMA
}

\author{
The Problem of Understanding / Living the Quran in the Formation of the \\ Islamic Individual and Society: Profound and Superficial Reading
}

\section{Mustafa CORA*}

\begin{tabular}{cr}
\multicolumn{2}{c}{ Makale Bilgileri } \\
\hline Geliş Tarihi: & 20.04 .2020 \\
Kabul Tarihi: & 26.11 .2020 \\
Yayın Tarihi: & 25.12 .2020
\end{tabular}

Özet

İnsanliğın hidâyet rehberi olan Kur'ân'ın anlaşılması, özümsenmesi, insanın yaşamını şekillendirmesi keyfiyet ve nitelik yönünden her zaman irdelenir ve sorgulanir olmuştur. Bu konuda İslâm literatüründe yer alan pek çok tartışmayı görmek ve birbirinden çok farklı görüşlerle karşılaşmak mümkündür. Bu görüşler, insanın her iki cihanda mutlu ve huzurlu olmasını sağlayabilecek, daha onurlu ve müreffeh bir hayat tarzının dünyada inşa edilmesi konusundaki arayışlar olarak değerlendirilebilir. Bu bağlamda Kur'ân'ın taleplerinin yine onun maksadına uygun ve içtenlikle benimsenerek gerçekçi bir şekilde karşılanması ve bunların bir yaşam biçimine dönüştürülerek Kur'ân'dan yeterince faydalanılması, her şeyden önce onun sıhhatli ve muhtevâsina uygun olarak anlaşılmasıyla mümkün olur. Bu da insanın Kur'ân'ı anlama kapasitesi ile alâkalı bir durumdur. Nitekim hitabı her ne kadar bütün insanlara yönelik olsa da onun ilâhî ve muciz bir kelâm olması, kulların kapasitelerinin farklılık arz etmesi ve onun anlaşılmasının uzmanlığ gerektirmesi gibi nedenlerden ötürü insanların ondan çıkardıkları anlamlar da farklılık gösterir. Her hâlükârda onu anlamaya çalışırken insanda bulunması gereken samimiyet, objektiflik ve liyakat ile onu sağlıklı ve doğru bir şekilde anlayabilmesi her zaman zorunlu bir ihtiyaç olarak onun önünde durur. İnsanın sergileyeceği eylemlerin, Kur'ân'a uygunluğu, ondan çıkartılacak bilgilerin doğruluğu ile de alâkalıdır. Zira insanın maddî ve manevî yönüyle alâkalı ilkeler, talimatlar, öneriler ve talepler ondan alınır. Onun taleplerinin ardındaki mâna ve hikmet de dikkate alınarak Kur'ân'ın içeriğine uygun olarak içsel ve dişsal eylemler şeklinde içtenlikle yerine getirilmeleri de mümin/müslüman kul için zorunluluk ifade eder. Zira Kur'ân, maddî ve manevî taleplerinin insanın hayatında yerini almasına yönelik olarak onun muhtevâsına muvâfik şekilde karşılanacağı tezâhürlerin/belirtilerin olmasını da öngörür. Bunlar aynı zamanda insanın, ona uygun ve duyarlı bir şekilde onu yaşadiğının belirtileri olarak da ifade edilebilir. Hal böyle olunca söz konusu derûnî ve zâhirî tezâhürlerin Kur'ân içeriği ile ne derece uyuştuğu, bu konuda ne kadar samimiyet içinde olunduğu ve bunların hangi maksatla yapıldığı gibi sorular ile Kur'ânî ölçülere göre İslâm'ı yaşama biçiminin sorgulamasının gerekliliği de akla gelir. İşte bu çalışmayla böyle hususlar irdeleyerek Kur'ân'ın kiraatinden, tefsirinden maksadın ne olduğu, onun nasıl anlaşılması gerektiği, şekilcilikten ve yüzeysellikten uzak bir biçimde içselleştirilerek yine Kur'ân'in ruhuna uygun bir şekilde yaşama dönüştürülmesinin nasıl olması gerektiği gibi meseleler hakkındaki görüşleri, mukâyeseleri ve önerileri yukarıda anılan bağlamda ortaya koyma gayreti içinde olduk.

Anahtar Kelimeler: Kur'ân Okumak, Kur'ân'ı Tefsir Etmek/Anlamak, Kur'ân'ı Derûnileştirmek, Kur'ân'ı Yaşamada Şekilcilik, Kur'ân ve Hayat.

\footnotetext{
* Dr. Öğretim Üyesi, Hacı Bayram Veli Üniv. İslami İlimler Fak., Tefsir Anabilim Dalı, mustafa_cora@hotmail.com , https://orcid.org/0000-0001-6694-2103
} 


\section{Giriş}

Kur'ân insanın yaratılış gayesi doğrultusunda fert ve toplum olarak onun görevlerini ve sorumluluklarını muhtevidir. İnsanın ondan ilgili bilgileri öğrenerek uygulaması ve neticede bununla sınanması söz konusudur. ${ }^{1}$ İnsanın, onun kendisine yüklediği sorumlulukları, görevleri ve mükellefiyetleri ondan çıkartması hem bir ihtiyaçtır hem de bir zorunluluktur. Bu nedenle insan, bir kul olarak bunları öğrenme ve hayatını onlara göre tanzim etme sorumluluğu ile karş1 karşıyadır. (Bakara 2/185; Hac 22/78; Kamer 54/17, 22).

Kur'ân iniş sürecinde hayatla iç içe olmuş ve o, ilk emri olarak oku ('Alak 96/1) mesajıyla gelmiştir. "Oku” emri, kök ve mefhum bağlamında kıraat (Buhârî, 1992: Ezân 104; Tirmizî, 1992: Salât 44) kelimesi ile ilişkili olup bu çerçevede ama farklı şekillerde ve mânalarda yer aldığ1 Kur'ân'da, kıraat şeklinde geçtiği hadislerin büyük çoğunluğunda, genellikle tilâvet kelimesi ile her ikisinden kastedilenin, Kur'ân'in lafız olarak usulüne uygun ve güzel okunmasını; onun doğru anlaşılmasını ve bunun samimi amel olarak davranışa yansıt1lmasını ihtiva (Seyyid Alizâde, 1320: 51; İsfehânî, t.y.: 75, 187, 401, 402) ve ifade edecek şekilde düşünülmesi mümkündür.

Bu nedenle Kur'ân'ın tilâveti temelde ve bir bakıma iman-amel dengesizliği şeklinde ortaya çıkan ahlâki soruna da bir işaret ve çözüm demektir. ${ }^{2}$ Dolayısıyla Kur'ân'in anlaşılmasında hassas davranarak ondan alınacak sağlıklı bilgilere dayanarak düzgün bir dini yaşantı ortaya koyabilmek amacıyla derûniliğe (içselleştirmeye) de önem verilmesi gerektiği anlaşılmaktadır. İmanın amele yansıması ne derece önemli ise Kur'ân'ın lâfzî tilâvetinin de iç/derunî bir okumaya dönüşmesi o derece önemlidir. Zira içselleştirilmiş bir inanç amele yansımaya başlamış demektir (Eyüpoğlu ve Yıldız, 2016: 163-198). ${ }^{3}$ Sosyal psikolojik açıdan da doğruluğuna inanılan bir bilginin davranışa yansımasının üç temel boyutundan söz edilmektedir (Eyüpoğlu ve Usta, 2019: 25): Örneğin 'kırmız1 1şıkta neden dururuz?' sorusu ile 'neden namaz kılarız?' sorusu benzerlik arz etmektedir. Polisin yazacağ1 cezadan korkarak kırmızı 1şıkta durmak zorunlu veya körü körüne bir itaattir ve sosyal psikolojik açıdan bu davranışta bilinçli uyma oranı çok zayıftır. Öğretmenin hatırı için kırmızı 1şıkta durmak da özdeşleşme neticesinde yapılan bir davranıştır ve bunda da bilinçli uyma oranı orta derecede sayılır. Bilinçli uyma oranının en çok bulunduğu tutum ise "benimseme" düzeyinde yani doğruluğuna gönülden inanılarak yapılan davranıştır. Bu

\footnotetext{
1 Bunun için âdeta buna teşvik edercesine Kur'ân'ın öğrenilmesinin, anlaşılmasının ve yaşanmasının kolaylaştırıldığı veya o tarzda sunulduğu bildirilir (örneğin, Zâriyât 51/56; Mülk 67/2).

2 Kur'ân, insanlık için en son hidâyet rehberi ve ilâhî bir kitap olması hasebiyle kendisinin okunmasını, anlașılmasını ve tilâvetinin amele yansıtılmasını talep etmektedir. Bir bakıma iman-amel arasında anlamlı bir dengenin kurulmasını önemsemektedir. Bu zaten ahlâki açıdan da insanlığın en temel meselesidir. Örneğin dünyada iman-amel farkı yani 'Ínanıyorum ama dindar değilim' diyenler \%32; Türkiye'de bu oran \%24'tür (Usta ve Eyüpoğlu, 2019: 55). Kısaca günümüz dünyasının asıl sorunu iman-amel dengesinden gittikçe uzaklaşmaktır.

3 Kur'ân'in bu anlamda okunma biçimlerinin irdelendiği bir çalışma örneği Eyüpoğlu ve Yıldız, 2016, 163-198'e bak1labilir.
} 
düzeydeki bir tutumda inanç ile davranış birbirini tam dengeli bir biçimde tamamlamaktadir.

Kısaca bir davranışın inanç boyutu ile eylem boyutu arasında daima tamamlamacı bir ilişki söz konusudur ve bu denge ahlâki meselelerimizin özünü teşkil eder. Kur’ân her zaman ilkesel olarak dosdoğru olan dinin (Beyyine 98/5; Rûm 30/30,43; Yusuf 12/40), kaynağı olan sahih bir bilgi ile yaşanmasını ister. Yani Kur'ân'ı doğru anlarsak ve ona da samimiyetle inanıyorsak, ondan anladığımızı amele yansıtma ihtimali en yüksek derecede olacaktır.

İnancın içselleştirilmemesi yani samimiyetin olmaması meselesi insanlığın başlangıcından günümüze kadar devam eden en önemli ahlâki bir meseledir. İslâm'ın ilk dönemlerinde de Kur'ân ve sünnetin önemsediği bu husus örneğin sûfi hareketlerinde de görülmüştür. İslâmî ilimlerin diğer alanlarında da bu hususta benzer söylemler, tenkitler her zaman mevcut olmuştur. Bu bağlamda Kuşeyrî (ö.465/1072)'nin sûfileri olduğu kadar her dindarı ve Müslümanı da ilgilendiren kayda değer nitelikte eleştirileri olmuştur (Kuşeyrî, 2001: 37; Çağırıc1, 2013: 111).

Anlayış olarak her zaman daha iyisini hedefleyen sûfî yaşantıda bile dini ve ahlâki zayıflama olması dinin içselleştirilememesinden kaynaklanmaktadır. Yani inanç-davranış veya iman-amel dengesinin sağlıklı olması, Kur'ân'ın hem doğru anlaşılmasına ve hem de ona samimi iman edilmesine bağlıdır. Bunun diğer bir adı da derûnî okuma olmaktadır.

$\mathrm{Bu}$ yönde Kur'ân, iman-amel dengesinin korunduğu veya inancın eyleme yansıdığı bir tutumu tavsiye eder, emreder. Öyle ki, sâlih/güzel ve içten olan amellerle dini şuur da güçlenir. Örneğin namaz k1lmak (Ankebût 29/45; Meâriç 70/22, 23) gibi ibâdetler bu kategoriye dâhil edilebilir. Namazda hem inanç ibâdete yani kısmen davranışa dönüşmekte ve "kötülüklerden uzak tutacak şekilde bir namaz" tavsiye edilmekte ve bir sonraki aşamada inanç tam ahlâki davranış halini almaktadır. Yani inançla tam ahlâki davranış arasında namaz köprü vazifesi görmektedir (Eyüpoğlu ve Perşembe, 2018: 79-96). Bu bağlamda namaz, âhirete dair bilinçli bir hal ile onun duygusunu ve saygısını taşıma, namuslu olma, yalandan uzak durma, iffetli ve doğru olma, ihtiyaç sahiplerine yardım etme gibi güzel davranışların yapılması hususlarında katkı sağlamaktadır. Böylece âyette (Meâriç 70/19) dile getirilen ve insanın doğasında var olan bencillik, nankörlük ve tahammülsüzlük gibi huyların yenilmesi mümkün olur ve onlara karşı güçlü bir irâde geliştir. Bu netice bir mecburiyet olarak kendiliğinden ortaya çıkmış olur (Karaman ve diğerleri, Ankara: 2014, 380-381).

Kur'ân'da ayrıca din ile ahlâki erdemler arasındaki ilişki de çok net olarak görülebilir. Örneğin âyette (Meâric 70/22.), sürekli namaz kılan kişi, sabırsız, hırsl1, feryat eden, cimrilik

\footnotetext{
${ }^{4}$ Aykırı görüşler olsa da Kuşeyrî’ye et-Teysîr fì İmi't-Tefsîr (Tefsîru'l-Kebî̀) adlı bir eser de atfedilmektedir. Bu konudaki farklı görüşler için örneğin Uludağ, 2002: XXVI,474'e bakılabilir.
} 
yapan (Meâriç 70/19-21) kişilerden farklı olarak değerlendirilir. Demek ki, gerçek hâliyle kılınan bir namaz ile elde edilecek erdemlerle insana böyle bir niteliği kazandırabilir.

Kur'ân'ın doğru okunması, doğru anlaşılması ve böylece içselleştirilerek yaşama dönüştürülmesi hususları, ahlâki hayatımız için merkezi öneme sahiptir. $\mathrm{Bu}$ derûnî okumaya işaret etmektedir. Derûnî okumanın olduğu yerde, iman-amel dengesinin bozukluğuna işaret eden yüzeysel okumaya yer kalmaz (Çakmaklığlu, 2018: 9).

Bu çalışmada kısaca Kur'ân'ın doğru okunması, doğru anlaşılması ve içselleştirilerek yaşanması arasındaki ilişkileri derûnilik-yüzeysellik karşıtlığı içerisinde değerlendirmeye çalışacağız. Bunun için özellikle konuyla ilgili âyetler yanında hadislerden de faydalanacağız. Zira Hz. Peygamber'e Kur'ân'ı tebliğ ve açıklama vazifesi de verilmiştir (Nahl 16/44). Kur'ân'ı okuma eylemi bir bakıma uyma davranışı olduğu için, zaman zaman değerlendirmelerimizde sosyal psikolojik yorumlardan da yararlanacağı.

\section{Kur'ân'ı Okuma Keyfiyeti ve Okuma Maksadı}

Bir şeyi okumak, sadece lafızlarını telaffuz etmek veya sırf onları okumaktan ibaret değildir. Okunan yazının içeriğinin ve anlamının çözülmesi veya kavranması da söz konusudur. Bunun için zihnin anlama mekanizmasının harekete geçmesi, gayret sarf etmesi de gerekir (Kâf 50/37).

Burada okuma bağlamında daha ziyade Kur'ân okunurken veya dinlenirken onunla irtibat kurulması, algılanması, anlaşılması ve bunların keyfiyetleri veya o esnada insanda husûle gelen ahvâl gibi hususlar üzerinde durmak istedik. Dolayısıyla Kur'ân'in okunmasıyla alâkalı ifadelerden özellikle öne çıkan kıraat ve tilâvet kavramlarına kısaca değinmek yerinde olacaktır.

a- Kıraat “ قراءة: Sözlükte, okumak, tilâvet etmek, telaffuz etmek, harfleri/kelimeleri bir birine eklemek veya katmak (Ferâhîdî, 1424/2003: 369,370; İsfehânî, t.y.: 401,402) demektir. Bu, sesli, sessiz, nağmeli, nağmesiz her hangi bir şekilde okumak veya tilâvet etmek olarak anlaşılabilir. Kıraat kelimesi bir mastardır, isimdir ve kendisiyle aynı kökten gelen Kur'ân kelimesiyle de kök anlamı itibariyle eş mânalı bir kelimedir (Ferâhidî, 1424/2003: 369,370; İbn-i Manzûr, 1999/1419: 145-150). ${ }^{6}$ Okumanın keyfiyetine işaret eden kıraat kavramı, Kur'ân'da bu bağlamda ve mefhumuyla irtibatlı kullanılır ve hadislerin büyük çoğunluğunda (Buhârî, 1992: Ezân 104; Tirmizî, 1992: Salât 44; İbn Mâce, 1992: İkâme 11) ise bizzat kıraat kelimesi olarak geçer.

\footnotetext{
${ }^{5}$ Kur'ân'da bu kelime ( قراءة) bulunmaz. Ancak onunla aynı kökten gelen ve genellikle isim ( القرآن), fiil ve az bir kism1 da mastar olarak toplam seksen dört kere geçer. (Mu'cemu Elfâzi'l-Kur'ân'il-Kerîm, 1409/1989: 888,889).

${ }^{6}$ Burada şunu da belirtmek gerekir ki, Kur'ân, 'fu'lân' vezninden “çokça okunan anlamında” mübâlağalı ism-i fâil (isim ve mastar) olmakla birlikte, okumayla alâkalı diğer tüm mânaları da ifade eder.
} 
b-Tilâvet “ تلاوة: Sözlükte, okumak, anlamı düşünmek, tâbi olmak, ardından gitmek (Ferâhîdî, 1424/2003: 189; İbn Fâris, 1399/1979, 351; İbn-i Manzûr, 1999/1419: 49,50; İsfehânî, t.y.: 75) vb. anlamları ifade eder. Mastar bir kelime olup aynı kökten gelen "tülüvv",

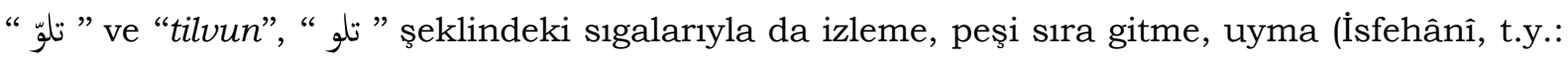
75; İbn Fâris, 1399/1979: 351; İbn Manzûr, 1999/1419: 49,50) gibi anlamları taşır. Bu kavramla da bir kelimenin veya Kur'ân'ın okunması ifade edilir. Zaten o, bir kelâmı, özellikle Kur'ân'ı okumayı anlatan, onun tertil ve tecvit usûlü üzere okunmasını ifade eden bir kelimedir. Bu meyanda onun Kur'ân'ı özenle, tertiple, tecvitle okuma veya telaffuz etme ve mânasını düşünüp anlayarak onunla amel etme gibi anlamları barındırdığı ifade edilebilir.(Seyyid Alizâde, 1320: 51,52; İsfehânî, t.y.: 401,402).

Tilâvet ve kıraat kavramlarının, anlamları ve üstlendikleri görevleri birlikte düşünüldügünde bunların hemen hemen eş anlamlı oldukları kanaatine varmak mümkündür. Bununla birlikte tilâvetin zaman zaman okuyarak, zaman zaman da uyarıları dikkate alarak Allah'ın kitabını izlemeyi (sosyal psikolojik ifadeyle ona uymayı) ifade ettiği görülür. Her ne kadar kıraat her çeşit okuma olarak düşünülse de tilâvetin özellikle ondan daha özel bir anlam ifade ettiği de vâkidir. Dolayısıyla her tilâvet kıraattir, denilebilir ama her kıraat tilâvettir, denilemez.(İsfehânî, t.y.: 187; Taberî, 1388/1968: 493).

Bu ifadelerden Kur'ân'ı okumanın, uyarı ve teşviklerinin farkına varmak, emirlerini samimi davranışa dönüştürmek anlamina geldiğini (Çetin, 2012: XXXXI,155) söylemek mümkündür. Bu açıdan bakıldığında, Kur'ân okumanın sadece ibâdet olamayacağı; yukarıda da ifade ettiğimiz üzere, ibâdetin, inanç ile ahlâki davranış arasında köprü oluşturduğu daha net anlaşılacaktır.

Bakara sûresinde yer alan âyette geçen “...el-Kitâbe hakka tilâvetihî...”, “...Kitabı, gereğince okuyanlar..."8 ifadesinin açıklanmasında önemli müfessirlerden bazılarının tilâveti veya Kur'ân okumay1 (Taberî, 1388/1968: 519-521; Fîrûzâbâdî, 1370/1951:14 vd.) onu indirildiği şekliyle tane tane, hakkını vererek; düşünerek; huşû, tefekkür ve tedebbürle okumak; onunla kastedilen mânanın dışında onu yorumlamamak, ona tâbi olmak, müteşâbihine inanarak muhkemiyle amel etmek, haramını haram, helâlini helâl kabul etmekle birlikte hakkını vererek onunla amel etmek şeklinde açıkladıkları görülür. (Taberî, 1388/1968: 519-521; Râzî, 1401/2000: 30; Fîrûzâbâdî, 1370/1951: 14).

Gazzâlî̀ye göre, Kur'ân ancak dilin, aklın ve gönlün iş birliği ile okunabilir. Bu şekilde dil okur, akıl okunanı tercüme eder, kalp de bunlardan gerekli dersi çıkarır veya alır (Gazzâlî, t.y.: 295). Kaldı ki, bizzat Hz. Peygamber de tecvîd kurallarını uygulayarak (Buhârî, 1992: Fedâilü'l-Kur'ân 29) Kur'ân'1 yavaş yavaş, tane tane, tefekkür ve tedebbürle okuyordu (Tirmizî, 1992: Fedâilü'l-Kur'ân 23). Öyle ki, kimilerine göre onun okunması zikir ve

\footnotetext{
7 Kur'ân'da bu kelime birkaç yerde isim-mastar (تلاؤ) ve genellikle de onunla aynı kökten türemiş fiil olarak toplam altmış iki yerde geçer (Mu'cemu Elfâzi'l-Kur'âni'l-Kerîm, 1409/1989: 195,196).

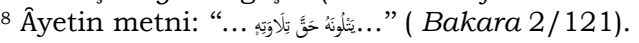


tesbihâttan daha efdaldir. $\mathrm{Bu}$ bağlamda onun güzel okunması veya dinlenmesi konusundaki anlayışın ve keyfiyetin irdelenmesi önem arz eder. Muhâsibîyye göre de Kur'ân'a yakın olmak onu izlemeyi ve onunla amel etmeyi gerektirir (Muhâsibî, t.y. 12 vd.). Kur'ân okumak bu anlamda sadece lâfzî okunuşu ifade etmemektedir.

Kur'ân'1 okuyan; onun usulüne uygun, hakkıyla okumas1, onu anlaması ve onunla amel etmesi gibi bir gerçekle karşılaşır. Zira onun kıraatinin okuyanda zihni yani derûnî değissimlere vesile olması beklenmektedir. Kur'ân daima insanı hidayete sevk edecek bir yönde değiştirmeyi arzu etmektedir. Dolayısıyla Kur'ân okuyanda bu yönde bir değişim olmuyorsa, onu hakkıyla tilâvet etmeyi başaramıyor demektir.

"İnananlar ancak, o kimselerdir ki Allah anıldiğı zaman kalbleri titrer, âyetleri okunduğu zaman bu onların imanlarinı artırı (kuvvetlendirir). Ve Rablerine güvenirler; namaz kılarlar; kendilerine verdiğimiz rizıktan yerli yerince sarf ederler" (Enfâl 8/2,3). Onlarda oluşan bu güzel hâlet-i rûhiyenin ve hassasiyetin devamı da gelir. Öyle ki, burada Kur'ân'ı okuyanın ondan etkilenmesi ve de bunun ardından güzel amele yönelmesi hâli bir şekilde vuku bulur.

Kur'ân'ı sadece okumakla olabileceği gibi dinlemekle de ondan nasiplenilebilir ve ondan elde edilmesi beklenen duyarlılik yakalanabilir. Nitekim Hz. Peygamber de onu başkasına okutmuş ve dinlemiştir. Örneğin bir gün o, Abdullah İbn Mesûd (r.a.)'dan Kur'ân okumasını istemiş, o: "Ey Allah'ın Resûlü, Kur'ân sana nâzil olduğu halde ben sana nasıl okuyayım" demiş, buna karş111k o da: "Onu başkasından dinlemeyi severim"(Müslim, 1992: İstimâu'l-Kur'ân 1905) buyurmuşlardır.

Kur'ân'ın kıraatinin adetâ Allah ile konuşuyormuş gibi içtenlikle (samimiyetle; derûnî bir biçimde) icra edilmesi gerekir ki ondan duygusal ve zihni açıdan bir tesir elde edilebilsin. Kıraat esnasında oluşacak duygu tesiri (Karagöz vd., 2010: 20) ile ahlâki kavramlar kişinin kalbine iyice yerleşmiş olacaktır. Kur'ân, usulüne uygun, duygulu ve gönül birliğiyle okunduğunda veya dinlendiğinde, insanın gönlünde derin bir etki oluşturacak olan belagati ortaya çıkacaktır. İşte esasen Kur'ân gereği üzere güzel bir eda ile okunarak böyle bir iletişim yakalandığında, ondan ruhların ve gönüllerin gidalanması temin edilebilir; onunla sağlıklı diyaloğun oluşması ve güçlenmesi sağlanabilir. Zira Kur'ân, insanın nefsine, kalbine, ruhuna ve fikrine yönelik olan Allah Kelâmıdır (Sürmeli, 2006: 13).

Bununla birlikte $\mathrm{Hz}$. Peygamber'in bazı hadislerinde ashâbına, Kur'ân'ın güzelce öğrenilmesi ve okunması, ama özellikle ona tâbi olunması ve onunla amel edilmesi (İbn Hanbel, 1981: 428 vd.) konusunda emir buyurduklarına dair rivâyetler de mevcuttur. Nitekim bu yönde $\mathrm{Hz}$. Ömer’in bu hususla ilgili endişesini de burada belirtmekte yarar vardır. Zira onun, insanların Kur'ân'ı okuma, ezberleme meşguliyetlerinden dolayı hükümlerini terk etmelerinden endişelendiğini, korktuğunu (Kettânî, t.y.: 280) ifade etmiş olması, dikkatlerden uzak tutulmamalıdır.

Bu sebeple, Kur'ân'ın okunmasından veya taliminden maksat, inanç ile eylem arasında dengeli bir iletişimin kurulmasını sağlamaktır. Allah'a samimiyetle inanan, onun 
hoşlanmayacağı şeyleri de samimiyetle terk eder ve böylece Cibril hadisinde kastedilen ihsan derecesinde (Allah’ı görüyormuşçasına ona kulluk eden) bir Müslüman olabilir. Kur'ân kıraatinde esas olan onun sadece sözlerini okumak veya telaffuzunu öğrenmek ve öğretmek, sonra da bunları sadece tekrarlamak değil; bununla beraber mânalarının öğrenilmesini ve öğretilmesini sağlamak, hemen peşinden (daha doğrusu aynı anda) bu mânaları davranışa dönüştürmek olmalıdır (Buharî, 1987/1407: 1919). ${ }^{9}$

Alak sûresinin ilk beş âyeti ('Alak 96/1-5) ile Müzzemmil sûresinin ilk on âyetinin (Müzzemmil 73/1-10) indirildikleri ilk günlerde tertile (doğru yani tecvide) uygun tilâvet edilip anlayarak ve gereğine tabi olarak okumaya dikkat çekilmesi, değindiğimiz hususa işaret etmektedir. Her hâlükârda tertîlin, Kur'ân'in mânasını düşünerek onu okumak demek olduğunu anliyoruz (İsfehânî, t.y.: 187). Bu hususu daha da ileriye götüren Suyûtî̀ye göre, okunan şeyi anlayarak okumakla kıraat olur (Suyûtî, t.y.: 303).

Nitekim Türkçe'de de aynı şekilde okumak, bir şeyi öğrenmeyi, mânasını çözmeyi, yazının içeriğini anlamayı; bazı belirtilerden hareketle bir mânayı, gizli duyguyu, kavramayı, hissetmeyi ifade eder (MEB Türkçe Sözlük, 1995, 2154; TDK Türkçe Sözlük, 998: 1675,1676). O zaman onu okurken aklın, düşüncenin, bilincin, hislerin ve gönlün buna hazır olması, kalbin onunla birleşmesi veya ülfet etmesi gerekir.( Aynî, 1303: 351).

Bu durumda kul için Kur'ân'ı usulüne uygun okumak, üzerinde düşünmek ve onu içselleştirmek (davranışa yansıtmak) bir gerçeklik olarak ortaya çıkar. İşte o zaman, ihlâslı, gerçekçi ve içten gelerek yaşanan Kur'ânî bir hayat akla gelir.

\section{Kur’ân'ı Sağlıklı Kavrama/Algılama ve Onunla İletișim Kurma}

Kur'ân'ın insan gönlünü aydınlatması ve onun hayatına ışık tutması için her şeyden önce onun yaşama nasıl aktarılacağı hususunun çok iyi anlaşılması gerekir. Bu olmadan Kur'ân'ın, insanın ıslahı için ortaya koyduğu hasletler ve göstermek istediği nihai hedefler yeterli derecede kavranamaz ve bilinç sahibi olunamaz.

Kur'ân'ın içerik bütünlüğünün, anlam ve bağlam bütünlüğü çerçevesinde anlaşılması ve açıklanması son derece önemlidir. Bunu gözetmeksizin delilsiz ve sağlıklı olmayan bazı iddialarla onun anlaşılması adına bir takım anlamların ve açıklamaların ona yüklenmesi asla doğru olmaz. Bu konuda gerekli olan usûl, onun bilgi ve birikimle yorumlanması için oldukça iyi bir alt yapıya sahip olunmasıdır. ${ }^{10}$

Allah halk ettiği insanı, yaşadığı sosyo-kültürel şartları, ihtiyaçlarını ve Kur'ân'ın da maksadını göz önünde bulundurarak kendi dünyalarını inşa edebilecek yeteneklerle yaratmıştır (Şems 91/7-10). Bu bağlamda din âlimlerinin veya müfessirlerin de toplumun 1slahına katkıda bulunma, onlara örnek olma görevleri ve sorumlulukları vardır. Her

\footnotetext{
${ }^{9}$ Sünen'de hasen sahih olarak geçen bu hadis el-Bânî'ye göre sahihtir (Tirmizî, t.y.: 173).

10 Bu bağlamda tefsir alanıyla uğraşanlara lâzım olan tefsirin kâideleri, meseleleri ve yöntemleri gibi hususlara dair bilgi ve ayrıntılar için örnek olarak (Kâfiyecî, 1989: 46-80)'e bakınız. Söz konusu veya farklı bazı konular için de (Cerrahoğlu, 1988: 69,70; Zeydân, 396/1976: 261,262; Mesud Efendi, 1297: 22 vd.; Ateş, t.y.: 234; Yazır, t.y.: 3845-3847; Râzî, 1401/2000: 78; Reşid Rıza, 1366/1947: 192; Kırca, 1996: 196. vd.)'e bakınız.
} 
hâlükârda Allah'ın insanın dini ve beşeri dünyasını oluşturabileceği konusunda ona güveni vardır. (Buhârî, 1992: Bedu'l-Vahiy 1; İbn Mâce, 1992: Zühd 26).

Kur'ân hayatın değişken olmasına rağmen onunla irtibatını kurma ve devam ettirme istidadını taşıyan niteliklere sahip bir din sunar. Kur'ân'ın her şartta ve durumda özellikle gelişmelere göre isabetli anlaşılması ve uygulanması bir gereklilik ifade eder. Örneğin, Mecellenin usûle dair ilk yüz maddelik kısmının altmış yedinci maddesine muhâlif ve alternatif otuz yedi maddesinin de olduğu görülür.(Mesud Efendi, 1297: 30,31). Bu aynı zamanda çözüm alternatifini artırma ve istisna demek olup İslâm'in sosyal hayatın değişkenliğini ve esnekliğini karşılamaya uygun bir hâli olduğunu ifade eder. Zira sosyal hayat hiçbir zaman statik değildir ve Kur'ân'la gelen vahiy kültürü, insanın sosyo-kültürel yapısı ile muhatap olarak onun hayatıyla iç içe olma, ama kendi hayat biçiminin özünü ve temel ilkelerini koruma, değişimlere bir şekilde uyum sağlama kabiliyetini taşır.

Kur'ân'dan mevcut nitelikleri ile yeterince yararlanabilmek için sadece bilgi aktarmayla yetinilmemelidir. Onunla ilgili çalışmalarda işin usulüne yani Tefsir Usûlüne (Sabbağ, 1408/1988:10) ve sistematik düşünceye uygun gerekli hassasiyet gösterilerek bilgi de üretilmelidir. Bu, ondan oldukça isabetli ve sağlıklı yararlanmaya, davranış biçimleri elde etmeye ve bunları geliştirmeye katkı sağlayacaktır.

Kur'ân inanç ve ibâdetin yanı sıra ictimâî davranış prensipleri de vaz etmiştir. Böylece inancın kuru bir ilke olarak kalmamasını; hayatın içinde canlılık bulmasını ve asıl görevini bu şekilde ifa etmesini amaçlamıştır. Kur'ân'da bu konuda temel ilkeler ortaya konulmuştur. Kur'ân'ın amac1, kendi kimliğini kazanmış erdemli örnek insanlardan oluşan bir topluluk inşa etmektir. Çünkü örnek olsun diye meleklerden değil de Hz. Peygamber gibi insan cinsinden birisi görevlendirilmiştir. Allah, Hz. Peygamber örneğinde Kur’ân'daki prensiplere tutunulmasını, onların hayatla zinde bir iletişim kurularak sürekli güncel kalmasını talep etmektedir.

Kur'ân'ın mevcut sosyo-kültürel koşulları mutlak kabul etmediği ama onları örf köprüsü aracıllğıyla bir şekilde dikkate aldığı da görülmektedir ki Kur'ân bu dinamik yönü sayesinde evrensel bir niteliğe sahiptir. Örneğin sütannenin ücretini örfe bırakmaktadır. Müfessir veya fakih de buradan hareketle günümüzde bakıcı ücretlerinin nasıl olacağ1 konusunda işin usulüne uygun yorum yapabilmektedir. ${ }^{11}$ Böylece Kur'ân'in güncel meselelere zaman zaman ahlâki anlamda tavsiyelerde bulunduğu; hidayet yolunda kıyamete kadar insana rehber olmaya devam edeceği anlaşılmaktadır.

Her durumda Kur'ân sahip olduğu nitelikleriyle evrensel bir özellikte olduğunu ifade eder. Bu nedenle o, her zaman insanların inançlarına ve dini veya dünyevi ihtiyaçlarına

\footnotetext{
${ }^{11}$ Kur'ân'ın mevcut sosyo-kültürel koşulları yani örfü nereye kadar örnek aldığına dair mini istatistiksel bir çalışma örneği olarak Eyüpoğlu ve Okuyan, 2008: 175-213'e bakılabilir. Kur'ân'ın mevcut sosyo-kültürel koşullarla girdiği anlamlı/dinamik iletişim bize vahiyle hayat, madde ile mâna, din ile dünya, lafız ile mâna veya zâhir ile bâtın arasında tamamlayıcı bir iliş̧ki olduğunu göstermektedir. Bu konuda birkaç sosyal psikolojik irdeleme örneği olarak şunlara bakılabilir: Eyüpoğlu ve Yıldız, 2016, 163-198; Eyüpoğlu, Çelik ve Yıldız, 2017, 263-287; Eyüpoğlu ve Perşembe, 2018: 79-96; Eyüpoğlu ve Usta, 2019: 347-378.
} 
kıyamete kadar katk1 sunma potansiyeline sahiptir. $\mathrm{Bu}$ potansiyeli müfessirler, muhaddisler, fakihler ve diğer din bilimleriyle uğraşan uzmanlar kinetikleştirebilirler yani pratiğe dökmenin yollarını gösterebilirler. Bunun için başlangıç noktası daima Kur'ân'ın lafzının ve bu lafızlar üzerinden hareketle oluşturulan kadim geleneğin iyi öğrenilmesi ve ona hakkıyla sadakat gösterilmesi olmalıdır. Bu sadakat kaydıyla yapılacak içtihadî yorumlar hatalı da olsa elbette bir sevabı hak edebilirler. Sözü edilen bu sadakatin yokluğunda, İslâm'in özünün de buharlaşabileceği yönündeki endişeler kuşkusuz dikkate alınmalıdır.

Bir toplumun anlayış1, dünya görüşü, inancı ne olursa olsun Kur'ân onunla bir şekilde bağlantı kurulabilme imkânına sahiptir. Cahiliye toplumundan üretilen ilk örnek altın nesil buna işaret eden açık bir delildir. Çünkü Kur'ân'ın talep ettiği her meselede dini olanla dünyevi olan o derece uyumlu bir birlik oluşturmaktadır ki, adeta zekâtta sosyal yardımlaşmayı, kırmızı 1şıkta durmada da söze sadık kalmayı görmekteyiz. Bu noktada her dini olayın beşeri bir yönü ve her beşeri olayın da dini bir yönü olduğu görülür (Eyüpoğlu vd., 2010: 41-66). O halde İslâm'ın doğasındaki bu gerçeklik onun insan hayatıyla ilişkilendirilmesinde kolaylık sağlayıcı bir keyfiyet arz eder.

Kur'ân'ın içtimaî hayatla ilgili prensiplerinin, kısmen lâfzen ama genelde mâna olarak tüm beşerî ve sosyal meselelerle ilişkilendirilmesi mümkündür. Burada Allah tarafından daima beşeri ihtiyaçlara cevap sunulması arzulandığından, sırf Allah'a yapılan bir tapınmanın (örneğin namaz ibâdetinin) bile beşeri kötülüklerin azaltılması yönünde psikolojik bir tedavi amacı taşıdığı anlaşılmaktadır. Allah müstağnidir yani bizim tapınmamıza muhtaç değildir. Kullar beşeri dünyalarını daha ahlâki olarak mamur edebilsinler diye O'na yalvarırlar; O’ndan yağmur bereket isterler; beşeri kötülüklerden; görünür görünmez kaza, bela, âfet ve kötü niyetlerden korunmak için O’na yönelirler. Bu durumda Kur'ân'ın ahlâki ve sosyal ilkelerinin insan için ne kadar önemli ve gerekli olduğu da yine bizzat sosyal hayatta (İbn Haldun, 1990: 100-104) ortaya çıkar. Örneğin sözünü ettiğimiz dua olgusu ve kulluk sayesinde insan hem gönülden inanma, bağlanma ihtiyacını gidermekte hem de Allah'ın yeryüzünde insanı halîfe yapma irâdesi tecelli etmiş olmaktadır. Böylece Kur'ânî taleplerin özünde yer alan evrensellik tezahür etmiş olur (Râzî, 1401/2000: XXXIX, 243; Eyüpoğlu vd., 2010: 58). Bu sebeple dini duygu ve davranışlar salt alışkanlık haline gelmez. Örneğin bir birey alkol alma alışkanlığını sürekli olarak terk edebilir ama bir kez inananmıssa bu inanç Allah ile bir şekilde (az veya çok) iletişimini sürdürmeyi sağlayacaktır. Ama aynı süreklilik normal dünyevi alışkanlıklar için söz konusu olmayabilir ve kimileri değişebilir veya ortadan kalkabilir (Râzî, 1401/2000: 243; Eyüpoğlu vd., 2010: 58). Fakat insanın dinine olan sağlıklı bağl1lığı ve bu bağlılığın sürekliliği, Allah ile olan iletişimini hem oluşturmada hem de korumada ona katkıda bulunur.

Kur'ân ile sağl1klı iletişimde, Müslüman kimliğinin temel dinamiğini oluşturan inançsal değerlere, bunlarla ilişki kurulmasına ve hayattaki değişim dikkate alınarak bunların birer aksiyona dönüştürülmesine dair İslâm'ın sahip olduğu istidat yeterli ölçüde 
değerlendirilebilmelidir. Zira Kur'ân'da pek çok yerde imandan hemen sonra amelden söz edilir (Bakara 2/277; Hûd 11/23; Şuarâ 26/227; Eyüpoğlu, 2010: 56). Böyle bir durumda Kur'ân'in çeşitli emirleri karşısında Müminlerin değişmez parolası, "İşittik ve itaat ettik" şeklinde olmuştur (Nûr 24/51) ve hep öyle olmalıdır. Zira bilinmelidir ki Kur'ân bir talepte bulunduğunda o dini bir taleptir hem de güncel dünyevi faydaları ihtiva eden bir tekliftir, katkıdır. Bu anlamda Kur'ân'da itaat kavramını ele alan kısmen istatistiksel bir çalışmada şu sonuca varılmıştır:

“Kur'ân'ın uyma (itaat-ittiba) taleplerinin genel bağlamından ve onlara ilişkin verilen kısa istatistiksel bilgilerden anlaşılmaktadır ki, Kur'ân'da itaat, Allah'in emir ve yasaklarının;

a) Rasyonel açıdan iç tutarlılığı (akla yatkınlığı; doğruyu);

b) Ahlâki açıdan iyiyi;

c) Bilimsel açıdan tüm nesnel/müspet esbaba tevessülü;

d) Hukuki-siyasi açıdan meşruluğu (örfe uygunluğu);

e) Psikolojik açıdan ruhsal tatmini (ölümsüzlük arzusunu) ve

f) Sosyolojik açıdan da toplumsal huzuru/refahı sağlayıcı niteliklerini kavrayarak (benimseme/ihsan düzeyinde) onlara inanmak (itikat etmek) ve gereğini yerine getirmek (amel etmek) demektir” (Eyüpoğlu ve Usta, 2019: 347-378).

Kur'ân'la iletişime geçilirken onun taleplerinin ne kadar hayatla iç içe ve güncel olduğuna dair onun bu niteliği iyice ön plâna çıkarıldığında iman-amel dengesinde arzulanan seviyeye daha kısa sürede gelmek kuşkusuz mümkündür. Böylece Kur'ân'daki ferdî veya umumî değerler hakkında insanlarda daha olumlu bir bilinç oluşur; insanî değerlerle alâkalı şuur güçlenir ve dini emirlere bağl1lıkta tıpkı hava ile suyun zaruriliği gibi bir hissiyat oluşur. O zaman Kur'ân şuurunun tesisi ve istikrarı gerçekleşmiş; güçlenerek derinleşmesi sağlanmış olur. (Draz, 1983: 193,194; Aydın, 1991b: 220). Bu da ferdî ve sosyal bozulmaların önünde engel teşkil eder. Zira bu aşamada artık Kur'ân ile kurulan her diyalogda öz-söz, lafız-mâna, iman-amel birliği en üst seviyede yakalanmış olur. Bu nokta aynı zamanda ihsan derecesinde bir imana işaret eder ki arzulanan en üst düzeydeki iman da budur.

Kur'ân'in okunuşu, telaffuzu veya ezberlenmesi bir nevi salt ibâdet olarak algılansa da, yukarıda anlatılanlar çerçevesinde, ibâdetlerin de aslında iman-amel veya inanç-eylem arasında köprü oluşturduğu unutulmamalıdır. Ama bu husus yani okuma veya ezberleme ibâdeti, sadece okumayla yetinmek anlamına bürünmüş bir eylem keyfiyetinde olmamalıdır. Zira Kur'ân'ın aynı zamanda insan tarafından öğrenilmesi, okunması ve özellikle anlaşılarak yaşanması esastır (Furkân 25/52; Kâf 50/45; Okuyan, 2012: 449).

Her kul için saadet döneminde sahabenin (r.a.) Kur'ân'ı okuması; onu ilimle ve amelle birlikte öğrenmesi (Taberî, 1992/1412: 60 vd.) ve yaşaması bu anlamda çok güzel örnek olarak ortadadır. Bu anlayışa Mehmet Akif beyitlerinde çok güzel değinmiş ve vurgu 
yapmıştır. Zira ona göre de Kur'ân, sırf dua ve hatim kitabından ibaret olmayıp bizzat bir hayat kitabidır. (Ersoy, 1980: 170).

Kur'ân belirlediği vasıflarla donanımlı örnek insanlardan müteşekkil ve cihanşümul özelliklere sahip topluluklar oluşturmak ister. O ortamdaki kişilerin, kulluk ve halifelik vasfını taşımaları, kendilerinden Allah'nn râzı olacağı eylemlerde bulunmaları, aralarında şefkat ve merhamet üzere hareket etmeleri ve Kur'ân ile yoğun diyalog içinde bulunmaları istenir (Fetih 48/29. vd.; İsfehânî, t.y.: s. 86; Topçu, 2001: ss.13-15; Aydın, 1991: s.268; Sezen, 1994: s.86; Râzî, 1401/2000: XXXIX, 243).

Kur'ân, toplumunda insanların hem kendi aralarında hem de başkaları ile barış içinde olmalarını öngörür. (Reşid Rızâ, 1366/1947: 256-258; Kutup, 1991: 328). Onda huzur ve barış esas olmakla birlikte insanın hürriyeti ve hukuku da güvence altına alınır (Kutup, 1991: 329). Böyle bir topluluğun özünde sosyal bütünlük, toplumlar arası birlik ve kaynaşma yer alır. (Hucurât 49/13 vd.; Bayrakl1, 1999: 59). Zemahşerîye göre, Kur'ân'da yer alan ihvân (kardeşler) ifadesi, onların kendi aralarında şefkatli, içten ve tek bir buyrukta bir araya gelen topluluk olmalarını gerektirir (Hucurât 49/10; Zemahşerî, 1424/2003: 387).

Kur'ân'a göre herkes onun muhatabıdır ve her kişi insanlık ailesinin bir üyesidir. Tabii olarak buradan uluslararası bir topluluk fikrinin çıkartılması da mümkündür (Mâide 5/48; Hucurât 49/13 vd.; Hadîdî, 1978: 202,203; Siddıkî, 1990. 111-113; Özel, 1996: 419). O zaman bu topluluk, Müslümanlar arasında ayrılık, dağınıklık olmadan tevhit anlayışı üzere tek tek veya hep beraber bir bütün olarak Allah'a bağlanan bir topluluk olmuş olur. Bu toplulukta bir birey olmak, önce gönülden Kur'ân'a bağlanmayı, tevhit üzere ortak noktalara dayanmayı, gelişmeyi, bu şekilde kuvvetlenmeyi (Bûtî, 1987: 184,185), birlik ve kardeşlik üzere ortak bir anlayışla kaynaşan kalpler ile Allah'a bağlanmayı (Zemahşerî, 1424/2003: 387) gerektirir.

Her hâlükârda Kur'ân'dan alıp günümüz insanı için yorumladığımız bilginin yukarıda değindiğimiz hayatla içiçelik niteliğinin anlaşılır bir dille ortaya konulması gerekmektedir. İhtiyaçlarımızın Kur'ân'ın talepleriyle nasıl da uyumlu olduğunu en güzel şekilde ortaya koyduğumuzda, inanan bireylerin Kur'ân ile sağliklı diyalog kurmaları daha da kolaylaşacaktır. Kur'ân’’n istediği gerçek dünya da ancak bu yolla inşa edilebilir.

Kur'ân'da yer alan, Allah'ın irâdesine uygunluğu öngören, insanın yapısına ve mizacına muvâfık mânayı bize ilk sunan onun lafızlarıdır. Kur’ân lafızlarının vahiy döneminde hayatla kurdukları dinamik bağ1 ${ }^{12}$ yani tüm boyutlarıyla vahiy dönemini en güzel şekilde ortaya koyup, buradan hareketle günümüze sağl1klı kıyaslamalar yaparak geçmek meselenin özünü teşkil etmektedir. Hayatla iç içe olan bir din ile diyaloga geçmek ve

\footnotetext{
12 Kur'ân'da örf kavramına dair sade istatistiksel bir çalışma bize göstermektedir ki, İslâm Câhiliye ile iletişiminde onu ne tamamen dışlamış ne de tamamen kabul etmiştir. Câhiliye-İslâm iletişiminde hukuki bazı uygulamalar açısından kabul-ret-tadil oranları şöyledir: İbka: 8/28; İlga: 9/28 Tadil: 11/28. İslâm'ın beş şartı açısından ise söz konusu oranlar şu şekildedir: İbka: 2/12; İlga: 4/12 Tadil: 6/12 (Eyüpoğlu ve Okuyan, 2008: 193-196).
} 
bu diyalogu sürekli zinde tutacak bir içselleştirme (benimseme; ihsan) seviyesinde veya derûnî düzeyde tutum sergilemek elbette kolay olacaktır.

Kur'ân'ın hayatla iç içe oluşu bilgisi bize Allah'1 görüyormuşçasına (İbnu'l-'Arabî, 1998: 10) bir iletişim imkânı sunacaktır. Kur'ânî mânalar eylemlere dönüştürülürken her hâlükârda derûnî (içsel) ${ }^{13}$ bir yön ve yönelişi de beraberinde getirirler. Bu duygusal yön de gücünü esasında insanın fitratında bir yaratıcıya bağlanma arzusu ve ihtiyacının bulunmasından almaktadır. Çünkü insan bir davranışı -o davranış sırf kendi dünyevi yararı için vaz edilmişse dahi- onu icra ederken, maddi ihtiyacını giderme lezzetinin yanında, Allah'a kulluk ve teşekkür olarak vazifesini yapmış olmanın hazzını da almak istemektedir. Zaten insan esasen onu tanımak ve O'na (gönülden) ibâdet etmek için yaratılmıştır (Zâriyât 51/56). Gelinen bu noktada dini bilgi ve pratiklerin içselleştirilmesinin önemine de değinmekte yarar vardır.

\section{Kur'ân'ın Sunduğu İlim ve Eylemi (Ameli) Derûnileştirme}

Kur'ân'ı okumak işin başlangıcı olsa da esas olan onu anlamak ve anlaşılan hususu gündelik hayatta tatbik etmektir. Başka bir ifadeyle, Müminin Kur'ân'dan anladığını davranışlarına en kalıcı tutum değişimi dediğimiz içselleştirme (benimseme veya ihsan yani Allah'ı görüyormuşçasına O'na saygılı ve içten bir kulluk) seviyesinde yansıtabilmesi meselenin özünü teşkil etmektedir. Bu durum bizi Kur'ân'ın, insanın kalbî veya derûnî tarafıyla ilgili boyutuna götürmektedir. Kur’ân, insanın somut davranışları yanında niyeti, düşüncesi, imanı, takvâsı gibi soyut ve mânevî yönüyle de ilgilenir. ${ }^{14}$

Kur'ân'a göre kalbe atfedilen bir mesele veya eylem olarak ifade edilen iman, vahiyle ilgili taleplerin ve derûnî boyutlarla alâkalı kavramların en önemlilerinden biridir. $\mathrm{Bu}$ yönüyle o, konumuz açısından da uygun örnek olmaktadır. Meselâ bedevilerin kalplerinde henüz iman bulunmadığı bir zamanda (İslâm'ın) sözlük anlamı üzere teslim veya Müslüman olduk şeklindeki söylemleri dile getirmeleri hiçbir anlam ifade etmemiştir. Zira onlarda esasında derûnî (ve kalbî) tarafla alâkalı her hangi bir eylem henüz oluşmamış ve iman oraya girip yerleşmemiştir. (Hucurât 49/14; Mücâdele 58/22).

İnsanın derûnî yönüne işaret eden iman (Müfredât, "e-m-n” mad., 143; İsfehânî, t.y.: 143-146), kendisine dayanılarak yapılan dini pratikler ile hem varlığını sürdürür hem de onlarla güçlenir. Onun muhtevâsıyla alâkalı olan taat (itaat) ve İslâm kavramları da, şartsız teslim olma veya teslim etme, irâde, inkıyâd (Dînevî, 1393/1973: 479), bilme, bilinç, samimi olma gibi anlamlara gelmektedir. Bunların her ikisi de Kur'ân'daki işlevleri veya

\footnotetext{
13 Derûnilik: Gerçek Kur'ân (veya İslâm) yaşantısı (dindarlık) veya saf dini yaşantı bağlamında yapılan eylemlere veya pratiklere bağlı olarak insanın derûnunda ve bu yöne dönük ahlâken ve mânen meydana gelen yansımalarında iyileşme veya olgunlaşmaya yönelik içselleşme (veya içselleştirilme) hâlinde oluşan ahvâle gönderme yapılmak olarak ifade edilebilir (Çakmaklığlu, 2018: 9). Bu konuda ve ayrıca bir şeyin içselleşmesine dair geniş sözlük bilgisi için TDK Türkçe Sözlük, 1998: 267, 1044,2203; MEB Türkçe Sözlük,1995: 1399'a bakınız.

14 Örneğin Kur'ânî yaşantının temeli olan iman, onu anlamanın derûnî ve kalbî tarafiyla daha alâkalı bir kavramdır. Bunu ilgili bazı âyetlerden (Sâffât 37/84; Şuarâ 26/89 vd.) ve hadislerden anlamak mümkündür.

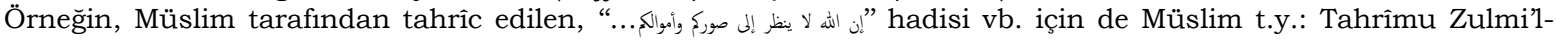
Müslimîn..., C.VIII, 11); İbn Mâce, t.y.: Kitâbu'z-Zühd, C.V, 254'e bakılabilir.
} 
üstlendikleri fonksiyonları yönüyle insanla ve yaptıklarıyla alâkalıdır. İman, eylemin, amelin öncesinde de beraberinde de onunla hep vardır. Bu nedenle onun varlığı ve niteliği, Kur'ân'dan alınan ve pratiğe dönüştürülen İslâmî emirlerle, tavsiyelerle veya ahlâki değerlerle bir şekilde irtibatlıdır.

Kur'ân'da, İslâm kavramı ve kendisi ile aynı kökten gelen bazı türevleri, çoğunlukla Allah'a yönelme (Bakara 2/112; Lokmân 31/22), geçmişten özür dileyerek kararlı bir şekilde Allah'a teslimiyet (Bakara 2/131; Mü'min 40/66) göstermek, hükümlerine boyun eğerek gerekenleri yapmak, işleri O'na havale etmek (Zümer 39/54 vd.)15 gibi anlamlarda kullanılır. İslâm kavramı da, bir şekilde insanın derûnî yönüyle ilgilidir. Onun ifade ettiği teslimiyet ve ittiba, hak ve doğru olanla alâkalı olup asla yanlışa teslim olmak veya boyun eğmek anlamına gelmez. Kur'ân muhtevâ olarak hem kendi hayat tarzını kabul ettirmeyi hem de tüm icaplarının yerine getirilmesi anlayışını ve duyarlılığını içerir (Nisa 4/71,72; Hac $22 / 77,78)$.

Kur'ân'da sıkça görülen “...iman edenler ve sâlih amel işleyenler...” ifadesi de iman ile amel arasında olması gereken ilişkiyi gösterir (Nisâ 4/173; Mâide 5/9, Kehf 18/107). Bu bir bakıma soyut (derûnî) ile somutun (zâhir/müşahhasın) ilişkisidir. Sadece "Ey iman edenler" şeklinde ifade edilen âyetler ile de amellerin eksikliğine işaret edilir (Nisâ 4/59; Tevbe 9/38 vd). Hayatta amel olarak tezahürü görülen iman, kendisine esas teşkil ettiği amele kemiyet ve keyfiyet yönünden katkı sağlar ve buna karş11ık amel de onu güçlendirir.

İslâm'da imana veya kabule konu olanlar için sadece tasdik yeterli olamaz. Çünkü amelin eksikliği mümin olma sıfatını olumsuz etkiler. Zira sâlih amel, kalpte oluşması öngörülen 1slaha canlılık verir. Ama masiyet yani sâlih amelin olmaması bu tamamlamacı ilişkiye zarar verir (Tevbe 9/32). Bu bağlamda Kur'ân'da (Enfâl 8/2; Teube 9/124; Fetih 48/4) imanın artış1 konusunda müfessir Molla Ali el-Kârî yaptığı teville, imanın kuvvetlenmesini, onun sadece tasdik (kabul etme) şeklinde değil; kemal ve kuvvet yönünden üstünlük olarak anlaşılması gerektiğini belirtir (Kârî, 1323: 79; Harputî, 1330: 258).

Kur'ânî taleplerin ihsan derecesinde bir hayatiyet bulması, teslimiyet, tevekkül, rıza, takvâ, samimiyet ve ihlâs (Hicr 15/40-42; Zümer 39/2,3; İsmâil Hakkın, t.y.: I, 16; IV, 311 vd.) gibi kalbî/derûnî eylemlerle desteklenmelerine de bağlıdır. Kur'ânî taleplerin içselleştirilmeleri bağlaminda Mevlânâ Celâleddîn-i Rûmî, amelin ve ibâdetin ruhtan yoksun ve mânasız olamayacağını dile getirir (Mevlânâ, 994: 16,22 vd.) Burada davranışlarda ve ibâdetlerde dâhilî âdâbın mutlaka gözetilmesi gerektiği ifade ediliyor.

Hz. Peygamber'in ve sahabenin hayatlarında faziletli ve erdemli olmak bir yaşam tarzı olmuştu. İyi bir Kur'ân yaşantısının özünde mutlaka ahlâkilik ve içtenlik vardır ve İslâm'la ahlâk (Kalem 68/4) homojen bir bütünün iç içe geçmiş iki yarısı gibidir. Sûfiler ve İslâm ahlâkçıları özellikle derûnî iyileşme, güzelleşme üzerinde önemle durmuşlardır.

${ }^{15}$ Bu konuda bak., Sülemî, 1421/2001: 201; İsfehânî, t.y.: 241; Taftâzânî: 1411/1991: 189; İbn Teymiyye, 1406: 30. 
Kur'ân'da yer alan ve bedenle alâkalı olan şekli hükümler yanında onun ruh ve mâna yönüne de dikkat edilmesinin gerekliliği ortadadır. Amellerdeki ruh ve mâna yönünün varlığ1 inkâr edilemez. Bu anlamda zâhir buyruklar ile bâtın (mâna) arasında da bir dengenin kurulması icap eder. Kur'ânî taleplerin lâfzî-manevî veya zahirî-bâtınî yönü arasında da var olan irtibat bu uyumu yansitir.

Kur'ân'ın istediği yaşantıyla İslâm ahlâkı (Çakmaklığlu, 2018: 7) ve ameli ortaya çıkar. Zira ibâdetlerde kötülüklerden uzaklaştırma amacı olduğu gibi ahlâkta da reziletlerden sakındırma hedefi söz konusudur (Çakmaklığlu, 2018: 5,7). Bu sebeple her ikisinin de ortak amacı, insanın içindeki iyileşmenin ve güzelliğin eylemlerle hayata geçirilmesini sağlamaktır. Bu bağlamda örneğin kalben hissederek kılınan namaz, rukû ve secde olarak sadece şekillerden oluşan erkândan ibaret değildir.

İbâdetlerin şekilleri, şartları, kuralları vardır ama bunlar akıl, ruh, kalp, duygu ve bedenle birlikte bütünlük oluşturularak yerine getirilmelidir. Bunların Kur'ân açısından sadece şeklen yerine getirilmeleri veya yaşanmaları tek başına yeterli olamaz. Kur'ân'daki bu derûnî-zâhirî bütünlük bağlamında mutasavvıflar kelâmcılara ve fikıhçılara karşı tenkitler yöneltirler (Sülemî, 1999: 5262; Serrâc,1914: 17). Bu bağlamda örneğin Kur'ân'1 yaşamak adına oldukça şekilci bir anlayışa yönelme veya aşırı teslimiyetçi bir ahvâle bürünme de tartışmaya açık durum arz eder (Çakmaklığlu, 2018. 16).

Kur'ânî hayat için ahlâk vazgeçilmez esastır. Ahlâki üstünlükleri tamamlamak ve bu konuda örnek olmak için peygamberler gönderilmiştir. Ahlâk, Kur'ân'da davetin en temel ilkelerinden sayılır (Beled 90/17; Asr 103/3; Yazır, XIII, 5844,5845; IX, 6079-6084). Öyle ki, bunlar kulun "emr-i bilma'rûf ve nehyi ani'l-munker", “...iyiliği emretme, kötülükten men etme..." (Âl-i İmrân 3/104; İzutsu, 1991: 281-283) sorumluluğu ve görevleri arasında yer alır. Kur'ân'a göre bir toplumda erkek olsun, kadın olsun herkes (Tevbe 9/71) bu minval üzere övgüye muhatap olur.

Burada iman-ibâdet arasında değişik ifadelerle vurgulaya geldiğimiz tamamlamacı ilişkiden (Eyüpoğlu ve Perşembe, 2019: 464-483), ibâdet ahlâk arasındaki tamamlayıc1 ilişkiye geçmiş olduk. Kısaca burada sadece namazın kötülüklerden uzaklaştıracağına dair Kur'ânî vurgu bile yeterli sayılabilir. İbâdetler açısından iyi durumda olamayan aslında ahlâk açısından da iyi seviyede olamaz ve tersi de böyledir. Ancak meselelerin veya olayların isimlendirilmeleriyle alâkalı farklılıklar olabilir. Meselâ yalan, hırsızlık, zina adam öldürme vb. din açısından haramdır; ahlâka göre ise bunlar birer kötü eylem ve rezilettir. Bir başka ifadeyle doğruluk, iffet, hilm, adâlet vb. Kur'ânî değerlerdir. Bunlar ahlâk açısından ise iyi ve fazilet olarak vasfedilir, değerlendirilir (Uysal, 2005: s.44). İbâdetler de ahlâktan soyut olamaz. O halde bunlar iç içedir. Nitekim Kur'ân'ın, İslâm'ın ve ahlâkın her ikisini birlikte yaşatma talebi vardır. İslâm da ahlâk da, fazilete, doğruluğa, samimiyete, ibâdete vb. yöneltir. O zaman İslâm'ın da ahlâkın da önem verdiği derûnilik (içsellik, benimseme, ihsan, samimiyet) de kendilerinde bulunur. Örneğin âyette (Hucurât 49/3; Tusterî, 1423: I, 149) 
ahlâki davranışlarla alâkalı kalbî, derûnî veya iç sınanmadan söz edilir. Buna örnek olacak nitelikte bir başka âyette (Hucurât 49/14) dünyevî her hangi bir beklenti olmaksızın ahlâk ile amelin din duygusu temelinde oluşarak inancın ve ruhun derinliklerine uzanmalarından ve yerleşmelerinden bahsedilir ki, bunlar içsellikle ve olgunlaşmayla alâkalı niteliklerdir.

Buraya kadar ifade edilenleri sosyal psikolojik bir dille ifade edecek olursak, davranışlarımızın veya ibâdetlerimizin şekli kısımları zahire göre muâmele görmemizi sağlar. Örneğin namaz kılmışsak bize Müslüman muâmelesi yaparlar veya kırmızı 1şıkta durmusssak kurallara uyan örnek vatandaş olarak algılanırız. Ancak bu şekli davranış veya amellerimiz yeterli değildir. İbâdetlere veya davranışlarımıza ait kalbi (iç, derûnî) bir yön de vardır. Örneğin kırmızı 1şıkta seve seve duracağımıza istemeyerek de durmuş olabiliriz. Benzer şekilde namazı seve seve kılacağımıza kendimizi biraz zorlayarak da kılmış olabiliriz. İşte derûnilikten, içselleştirilmişlikten veya ihsan derecesinde bir tutumdan kastedilen husus, bir davranış1 veya ibâdeti doğruluğuna tam inanarak ve onu duygusal bir hazla ifa edebilmektir. Ahlâk da din de böyle bir birey inşa etme amacında birleşmektedirler. Bireyin derûnî bünyesindeki inanç ahlâki davranışlarında hayat bulur (Aydın, 1992: 307, 308). Örneğin tasavvuf (veya ahlâk) açısından da erdemli veya faziletli insan demek, yaptığını doğruluğuna inanarak yani bilinçli olarak yapan ve bunu Allah rızası temelinde ifa eden kişi demektir (Çakmaklığlu, 2018: 17).

Kur'ânî yaşantıda yüzeyselliğe yer olsaydı örneğin Mâûn sûresinde, kulluk görevlerini gerçekçi bir şekilde yapmayanlar, buna uygun vasıflarla nitelenenler ve namazı ciddiye almadan onu kılanlar olarak kınanmazlardı. Zira onlar işin özünden uzak ve derûnî yönü olmayan bir namazla meşguldürler yani gösteriş amaçlı kılmaktadırlar (Mâûn 107/1-7; Karaman vd., 2014: 697,698). Hâlbuki Kur'ân'ın istediği namaz özenle yapılan bir şekille huşû içinde kılınan namazdır yani kişinin kendini Allah'in bizzat huzurunda hissederek kıldığı namazdır. Başka bir ifadeyle kalbe tamamen yerleşen bir iman ile arzulanan düzeyde samimi bir amele veya davranışa yönelmek mümkün olur (Hucurât 49/14,15; İsmail Hakk1, t.y.: IX, 75,77; Cevzî, 2013: C.5, 228,406).

Her insanın yeterince ve aynı dini hassasiyette ve kâfi derecede ahlâklı olduğu söylenemez. Ama ahlâkta dâhilî iyileşmenin en güçlü desteği dinden gelir. Kur'ânî ve ahlâki değerlerin kişilik açısından kendini yeniler olabilmesi için örneğin namaz, oruç gibi ibâdetler bir nevi dinamo vazifesi görür (Eyüpoğlu vd., 2010: 55). Bu gibi ibâdetlerin bilinçli ve içten gelerek yapanlar, Kur’ân nazarında yüksek dereceli ödüle layık görülmüştür.

Burada içselliğin keyfiyetiyle alâkalı olarak zekât çok yerinde bir örnek olabilir. Nitekim o, samimiyetle ve ihsan anlayışıla verilirse kişinin davranışlarında itaat ve hassasiyet açısından önemli derecede dönüşümler oluşturur. Kişinin Kur'ânî bilgiye dayalı böyle bir uygulaması, onun mânevî eğitimi ve bilinçlenmesi konusunda şüphesiz çok etkili olacaktır. Zira o zekât ibâdeti sayesinde, malın gerçekte Allah'a ait olduğu, kendisinin ise bir aracı vasfı taşıdığı ve azametin O'nun zatına mahsus olduğu, kendisinin ise mütevâzi ve 
hoşgörülü olması gerektiği anlayış ve bilincini kazanır. Zekât sayesinde mânen ve ahlâken olgunlaşmada mesafe katettiği görülür (İbnu'l-‘Arabî, 1999: II, 253; İbnu'l-'Arabî, 1919. XI, 253). O zaman kişi, öğrenilip ifa edilenlerin sadece şeklen değil, içselleştirilmesi gerektiği hususunu da fark eder.

Dinin anlaşılması ve yaşanmasında derûniliğe doğrudan işaret etmesi bakımından, "Gerçekten Allah sizin bedenlerinize ve suretlerinize, bakmaz; lâkin sizin kalplerinize, bir rivâyette ise: Ve çalışmalarınıza bakar" mealindeki hadisi şerif çok anlamlıdır (İbn Mâce, t.y.: Kitâbu'z-Zühd, V, 254; Cezerî, t.y.: IV, 523; Nevevî, t.y.: V, 103). Nitekim Kuşeyrî tarafından da gelenekte dini, ahlâki bozulmanın, yozlaşma ve dinin aslından uzaklaşmanın vb. var olduğu gibi hususlar hakkında iç eleştiri yapıldığına ve ilgili konulara parmak basıldığına işaret edilir (Kuşeyrî, 2001: 36,37; Hucvîrî, 1974: 239).

Derûniliğe vurgu yapan bir kavram olarak ihlâsı da burada anmakta yarar vardır. Gerçek bir mümin ve aklı eren herkes, yaptığı her şeyde aranacak olanın sırf Allah rızası olduğu bilincine sahip olmalıdır. Her ne kadar insanın içindeki ahvâl hakkında kesin hüküm vermek zor olsa da kişi amelini Allah'ın rızasını isteyerek yaparsa onun bir şekilde dışarıya dönük güzel yansımaları olur. Elbette sıddıkların ihlâsı niteliğinde mutlak olan bir ihlâsla olursa en güzel olan budur.(Draz, 2009: 355-369). Her hâlükârda ve bir şekilde ilâhî vahye ve bu duyguyla bir cevap vermek gerekir.

Yüce Allah Yahudiler'e şöyle demişti: “Size verdiğimize (Kitab’a) bütün gücünüzle, ciddi ve kararlı biçimde sarılın, içinde olanı hatırlayın..." (Bakara 2/63). Buna göre kitaba sımsıkı sarılmak, ihlâsla yani içten gelerek; derûnî bir biçimde talebe uymak anlamına gelmektedir.

Kur'ânî taleplerin içselleştirilmelerinde rehber kavramlardan biri de takvadır. Bu kavram bağlamında muttakilerin dini emirleri yaşamalarında titiz davranmalarından; cezalanmalarına sebep olacak şeylerden korunmalarından ve Allah'ın emirlerine özenle ve nehiylerine karşı da metanetle yaklaşmalarından söz edilmektedir (Bakara 2/2-5; Muhâsibî, t.y.: 127-128; Gazzâlî, 1982, III, 2; IV, 2; Kuşeyrî, 2001: 87).

Kur'ânî taleplerin içselleştirilmelerinde dikkat edilecek diğer önemli bir husus, İslâm ahlâkçılarının (veya sûfilerin) de işaret ettiği üzere, bazı hasletlerle ilgili alışkanlıkların kazanılmasında sürekliliğe, ısrara, eğitimde tekrara özel önem vermektir. Bu yöntem, eğitimde de her zaman önemini koruyan ve geçerli olan bir yöntemdir. Bununla amaç, Kur'ân'in muhtevasındaki ilâhî buyrukları 1srarla yaşamak ve böylece ahlâki prensiplere alışarak mânevi hassasiyetler kazanmak; güzel huyların oluşmasına ve kemâle doğru tedricen ilerlemek olmalıdır. Bu, eğitimsiz bir yetinin örneğin vicdanın tek başına hayrın veya şerrin ölçüsü olamayacağı iddiasıyla paralellik arz der.

Kur'ân'in da olumsuz eğilimlerin kırılmasında (Meâric 70/22-25; Beydâvî, 1314: I, 485) ve ahlâkla ilgili olumsuzlukların temizlenmesinde buna benzer bir yöntem izlediği söylenebilir (Meâric 70/19-21; Çakmaklıŏlu, 2018: 12). Bu bağlamda Kur'ân, iç eğitimin sağlanabilmesi ve güzel huyların yakalanabilmesi için sorumluluk duygusunun 
geliştirilmesini, ahlâk ve ibâdet niteliğinde olan güzel davranışların sıkça yapılmasını talep eder. Örneğin namaza devam etme, oruç tutma, yoksullara yardım etme, âhirette hesap verme duygusunu taşıma, yalan söylememe gibi ibâdetlere ve davranışlara işaret eder (Ankebut 29/45). Burada söylemek gerekir ki, insan zorlukları ve sürekli sıkıntıları göze alarak, güzel şeylerde çokça tekrar yaparak onları adâb ve güzel ahlâk haline getirebilir; böylece bu hususlarda alışkanlıklar, içsel güzel duygular kazanabilir (Kuşeyrî, 2001: 56).

Mümin, zâhiri ve fiili hayatın gerisindeki mâna ve hikmeti de gözetir ki, o zaman her ikisindeki (zâhir ve bâtındaki) bütünlük bir anlam ifade etmiş olur. Aksi takdirde emirler ve yasaklar sadece suretler veya basit birer hal olarak oluşmaktan başka bir şey ifade etmez (Kalın, 2017: 3 vd.).

İnsanın inancı ve ibâdeti ahlâktan soyut ve müstakil şekilde Kur'ân'da yer alan olgular olarak kabul edilemez. Aynı zamanda imanla yapılan taabbudi ibâdetlerle ve davranışlarla sonuçta ortaya çıktığı mütalaa edilen derûnî ve ahlâki olgunluktan söz etmek de gerekir. ${ }^{16}$ Ahlâki olgunluğu gerçekleştirmek tasavvufi açıdan nihai amaç olarak görülür (Çakmaklıŏlu, 2018: 17). İslâm âlimlerinden (veya ahlâkçılarından) kimilerine göre Allah'ı tefekkür ve cemâlini müşâhede anlayışıyla yapılan her eylem, en güzel amel olarak Allah'ı o işte görüyor veya müşâhede ediyormuş gibi yapılan eylem niteliğinde olur (Çakmaklığlu, 2011: 262).

Kur'ân yaşantısı veya gerçek bir dini hayat, gönülden veya kalbî duyguların ve hislerin birleştiği ve kaynaştığı davranışlarla olur (Aynî, 1303: IX, 351). Kur’ân bu tür hasletlere sahip olan yani derûnî bir iman ile onun davranışa yansımış şekildeki amelleri ifa eden kişiyi övmektedir (Hucurat 49/13; Zümer 39/9; Hökelekli, 1995: 235-236). ${ }^{17}$

Gazzâlî, ibâdetlerin ifasında veya Kur'ân kıratı esnasında hem şeklî kısma uygunluk ve hem de derûnî yöne riâyet meselesinde ikisinin de gerekli olduğunu; bir bakıma aralarında tamamlayıcı bir ilişki bulunduğunu ifade etmek istemektedir (Gazzâlî, 1939: IV, 366,367; Kirmânî, 1401/1981: I, 21-22).

İçsellik konusunda sahabenin pek çoğuyla alâkalı örnekler vermek de mümkündür. Bunlardan meselâ, İbn Mesud'un bir gece, “...Rabb’im ilmimi artır” (Tâhâ 20/114) âyetini okurken câzibesine kapılarak âyeti sabaha kadar tekrarladığı (Ebû Şâme, 1986/1406, 196); Abdullah $b$. Revâha'nın ise, Mûte savaşı öncesinde ve evinden çıkarken devamlı ağladığını gören eşinin, kendisine bunun nedenini sorması üzerine, cevaben, "İçinizden oraya (cehenneme) gitmeyecek hiç kimse yoktur. Bu, Rabbinin üzerine aldiğı kesin borçtur" (Meryem

\footnotetext{
16 Zira insan, öyle duygularla bağlantılıdır ki, sahih ve hassas imanı sayesinde Allah anılınca kalbi titrer, âyetler okununca imanı artar, sadece Allah'a güvenir, oruç tutar, namaz kılar, emr-i maruf ve nehy-i münkerde bulunur (Teube 9/111); varlığından veya servetinden Allah rızası uğruna nifakta bulunur (Enfâl 8/2-4); haram olan cana kıymaz, zina etmez (Furkân 25/68) vb. buyrukları içten ve isteğe bağlı olarak derûnî iman sayesinde, ilâhî rızayı gözeterek ve irâdesine dayalı ameller olarak yerine getirir. Bu durum insanın taabbudî ve ahlâkî davranışlarında şekil-öz dengesini korumakla mutlu olacağı anlamına gelmektedir.

17 Ayrıca, Hökelekli, 1995: 235-236’ya bakılabilir.
} 
19/71) âyetine ait sözleri düşünmekten dolayı ağladığını söylemesi (Ebû Nuaym, t.y.: I, 118)gibi örnekleri vermek mümkündür.

Hülâsa, Kur'ân'ın doğru öğrenilmesi (Buhârî, el-Câmiu’s-Sahîh, 1987/1407: VI, 263; Tirmizî, t.y.: V, 174; İbn Hanbel, t.y.: I, 58), doğru anlaşılması ve derûnî boyutuyla davranışa dönüştürülmesi nihâi hedef olarak görülmelidir. Kur'ânî bir yaşantının, gerçek ve özenli dini bir hayatın oluşturulması ancak böyle bir anlayışla mümkün olabilir (Çakmaklığlu, 2018: 6). Bu türden bir yaşantı yani zâhiren gerekli şartlara uymak yanında işin özü olarak içten de bir iştiyak duymak söz konusu olduğunda, özü sözü bir bireylerden oluşan güvenilir bir toplum inşa etmek çok daha kolay olacaktır. Bu tür bir toplumda kırmızı 1şıkta duran kişi, ona diştan şekli olarak doğru tabi olmak yanında bu uyma davranışını içten samimi bir duyguyla da desteklediği için hem ahlâki hem de dini bir davranışı kâmil derecede ifa etmiş olacaktır. Benzer şekilde böyle bir toplumda örneğin namaz kılan kişi de, namazın şekli yani dış şartlarını yerine getirerek kılmak yanında bu ibâdete içten samimi bir duygu da beslediği için söz konusu dini davranışı en kâmil derecede yerine getirmiş olacaktır. Gerçek namaz da kötülüklerden uzaklaştıracağından dolayı kişinin bu seviyede ifa ettiği bir namaz ibâdeti aynı zamanda en üst seviyede ahlâki bir davranış olacaktır. Kur'ân'ın öğretisinin öngördüğü tüm diğer ibâdetlerin ve ahlâki eylemlerin de bu çerçevede mütalaa edilmesi mümkündür.

\section{Sonuç}

Kur'ân, insanın ıslahıyla veya maddi-mânevi terbiyesiyle ilgili prensipler, talimatlar, tavsiyeler ve çözüm önerileri içerir. Bunları öğrenebilmek için onu okumak gerekmektedir. Kur'ân'in okunmasını ifade eden kiraat “ قراءة " kelimesi onda bizzat bu biçimde yer almaz ama bu kökten türeyen seksen dört kelime, tilâvet “تلاوة" kökünden de türeyen altmış iki kelime olarak Kur'ân'da geçer. Kıraatten (okumaktan) maksat, kısaca onun okunma keyfiyetidir. Kıraat ve tilâvet, ince birkaç istisna hariç tutulursa genel anlamda eş anlamlı olarak kullanılmışlardır. Kur'ân'ın kıraati/tilâveti esnasında muteber olan husus, aklın, düşüncenin, bilincin, hislerin ve gönlün o esnada hazır olması ve derûnî (gönülden) etkileşimin bir şekilde sağlanabilmesidir. Yani Kur'ân'ı dış/harici şartlar diyebileceğimiz tecvide ve Arapçanın kurallarına uygun olarak okumanın yanında esasen dâhili/derûnî şartlar olarak ifade edebileceğimiz içten gelerek mânevi aşkla/hazla da onu tilâvet etmek gerekmektedir.

Bu tür bir okuma Kur'ân'a duygusal olarak tabi olmayı ifade edeceğinden, böyle okuyan kişi onu hem hakkıyla anlamış ve hem de onun taleplerine en üst uyma davranışını ifade eden içselleştirme ile cevap vermeye başlamış olur. Bu şekilde Kur'ân insanı olumlu bir zihniyet değişimine de sevk etmiş olur. Zihniyet, davranışı derûnî bir sâik ile yerine getirmeyi ifade eder. Zira olumlu bir düşünceye (zihniyete) sahip olunursa, ahlâki ve dini eylemler sadece şekilsel veya yüzeysel olarak yerine getirilmiş olmaz. İşte kalıcı tutum 
değişimi, o davranışa içten gelen bir itici güç ile yönelmeye başlandığında oluşur. Bu noktada Allah'1 görüyormuşçasına namaz kılmak ile yine onu görüyormuşçasına kırmızı 1şıkta durmak özdeş davranışlar haline gelir. Bu kalıcı tutum değişimine sahip bireylerin çoğaldığı bir toplumun en kısa sürede her açıdan ilerlemesi ve gelişmesi mümkün olacaktır.

Kur'ân'ın kıraati, bir ihtiyaç veya ibâdet niteliğinde olmakla beraber bundan maksat, özellikle Allah'ın muradının anlaşılması ve gereğinin yerine getirilmesidir. Bu nedenle ondan anlaşılanın doğru olması ve muhtevâsına uygunluk göstermesi zorunludur. Kur'ân'ı doğru okuyup anlamak dış veya şekilsel şartların ifasının da gerçekleştirilmesi anlamına gelmektedir. Kur'ân'dan anlaşılanın en üst seviyede kalıcı tutum değişimini sağlaması yani gerçek davranışa dönüşebilmesi için, dâhili/derûnî şartların da yerine getirilmesi gerekmektedir. Dâhili/derûnî şartlar ise, değindiğimiz üzere içten gelen coşkuyla; mânevi bir haz hissederek; duygusal bir boyutla onu okumayı ifade eder. Lâfzen doğru okunup doğru anlaşılan bir metin, eğer içten gelen bir mânevi haz ile de okunmuşsa, onu okuyanın davranışının mutlaka iyiye doğru değişmesine vesile olacaktır. Bu durumda iman amelle kendini kanıtlayacak; amel de 'tekrar eğitimi' sayesinde imanı sürekli korumuş olacaktır.

Kur'ânî hayat, elbette mâna ve hikmetle beraber bünyesinde şekli unsurlar veya eylemler de barındırır. Kur'ân, kulun her davranışında ve ibâdetinde derûnî (mânevî) ve ahlâki bir tarafın bulunduğunu ve dâhili/iç yönünün daima daha iyiye doğru sevk edilmesi gerektiğini vurgular. Kur'ân, bu iki yön yani eylemlerimizin şekilsel yapisı ile o şeklin arkasında/içte (kalpte) yer alan ve onun esas itici gücü olan ahvâl (haz, mânevi aşk, coşku, mânevi dürtü, güdü) arasında tamamlamacı bir ilişki kurulmasını çok önemser. Başka bir ifadeyle, amel ile kalbî yön veya iman ile amel arasında daima tamamlayıcı bir ilişkinin canlı tutulmasinı önemle vurgular.

Bu meyanda Kur'ân anlayışının ve yaşantısının içselleştirilmesinin alâmetleri olarak, âyetler okunurken duygulanılması, etkilenilmesi, heyecanlanılması, hatta ağlanması, ondan bir şeyler anlamak için düşünülmesi, yaşama düşüncesiyle ve niyetiyle okunması, davranış ve fiillerin onun talepleri ile örtüşür olmasına özen gösterilmesi, bu bağlamda oluşan iç güzelliğin, kalbî derinliklerden gelen (derûnî) mutluluğun daha güzel şeyler yapmaya sevk etmesi veya kişinin içinde mutluluk hissinin uyanmasına vesile olması gibi hususiyetler örnek olarak verilebilir. Kısaca, Kur'ân yaşantısı veya gerçek bir dini hayat, kalbî duyguların, hislerim onunla kaynaşmasıyla olur.

Burada, sözü edilen bütün derûnî ve zâhiri ahvalle ilgili örnekleri, ahlâkı Kur’ân ahlâkı olan Hz. Peygamber önderliğinde sergileyen sahabenin, Kur'ân'ın muhtevâsına uygun olarak; hem içsel hem de pratik yönüne ağırlık vererek onu saadet döneminde hayata geçirmesi ve bu yönde paha biçilemez değerleri miras bırakmış olması kayda değer çok önemli bir husustur. Buna benzer bir içselliğin ve erdemliliğin hâkim olduğu bir yaşam biçiminde riyaya, şekilciliğe ve yüzeyselliğe elbette yer kalmaz. 
Son söz olarak, eylem ile inanç veya davranış ile derûnî olan (veya niyet) arasında; iman ile amel arasında olması gereken tamamlayıc1 nitelik, kul ile mabut arasında da oluşmalıdır. Kişi onu yaratana karşı kulluk vazifesini yerine getirirken sanki onu görüyormuş̧̧asına hareket ederse, bu en saf, gerçekçi ve kâmil bir tutum olacaktır. Dünyevî davranışlarımızın içteki itici gücü olarak niyetle veya diğer kalbî sâiklerle uyuşması nasıl önemli ise yani kırmızı 1şıkta doğruluğuna inandığımız için duruyorsak, benzer şekilde ibâdetlerimizi de sanki mabudu görüyormuşçasına samimiyetle ve aşkla yapmamız gerekmektedir. Aksi durumda yüzeysellik ileride riyakârlığa ve o da nifaka götürür ki, günümüzde insanlığın sorunlarının esas nedeni işte bu ahlâki çöküntüdür. Zira davranışlarımızın şekli kısmını derûnilik tamamlarsa, o zaman bu âdeta ruhun hayata canllık vermesine benzeyecektir. Aksi durumda ruh çekilince de hayat bitecektir.

\section{Kaynakça}

Ahmed b. Hanbel (t.y.). Musnedu Amed ibn Hanbel. Kahire: Muessesetu Kurtuba.

Ali el-Kârî, (1323). Minehu'r-Ravzi'l-Ezher fì Şerhi'l-Fıkhi'l-Ekber. Kahire.

Ateş, S.(t.y.). Kur'ân’ı Kerîm ve Yüce Meâli, İstanbul: Yeni Ufuklar Nşr.

Aynî, E. (1303). Umdetu'l-Kârî li Şerhi Sahîhi'l-Buhârî. İstanbul.

İbnu'l-'Arabî, M. (1919). et-Tedbîrâtu'l-İlâhiyye fî Islâhi'l-Memleketi'l-İnsaniyye. (nşr.: Henrig Samuel Nyberg), Kleinere Schriften des İbnu al-'Arabî içinde, (E.J. Brill), Leiden.

İbnu'l-'Arabî (1999). el-Futuhâtu'l-Mekkiyye. (haz.: Ahmed Şemseddîn), Beyrut: Dârul'lKütübi'l-İlmiyye.

İbnu'l-'Arabî (1998). Mevâkıu'n-Nucûm ve Metâliu Ehilleti'l-Ensâri ve'l-Ulûm. (thk.: Halid Şibl Ebû Süleyman), Kahire: Âlemu'l-Fikr.

Aydın, M. S. (1992). Din Felsefesi. Ankara.

Aydın, M. S. (1991b). Tanrı-Ahlâk İiş̧kisi. Ankara: Türkiye Diyanet Vakfı.

Aydın, M. (1991a). İlk Dönem İslâm Toplumunun Şekillenişi. İstanbul.

Bayraklı, B. (1999). Kur'ân'da Değişim Gelişim ve Kalite Kavramları. İstanbul: MÜİFAV Yay.

Beydâvî, N. (1314). Tefsîru'l-Kâdî el-Beydâvî (Envâru't-Tenzîl ve Esrâru't-Te'vîl). İstanbul: Dersaadet.

Buharî, E. ( 1992). el-Câmi’u's-Sahîh. I-VIII, İstanbul: Çağrı Yay.

Buharî, E.(1987/1407). el-Câmiu’s-Sahîh. Kahire: Dâru'ş-Şa’b. 
Buharî, E. (1987/1407). el-Câmiu's-Sahîh el-Muhtasar. (thk. Mustafa Dîb el-Beğâ), Beyrut: Dâru İbn Kesîr.

Bûtî, R. (1987). Kur'ân'da İnsan ve Medeniyet. (trc.: Resul Tosun), İstanbul.

Cerrahoğlu, İ. (1988). Tefsir Tarihi. Ankara: DİB Yay.

Cevzî, C. (2013). Zâdu'l-Mesîr fí İmit'-Tefsîr.

Çağırıc1, M. (2013). İslâm Düşüncesinde Ahlâk. İstanbul: Dem Yay.

Çakmaklığlu, M. M. (2018). Din-Ahlâk İlişkisi Bağlamında Dindarlık ve Derûnîlik: Şekilci ve Yüzeysel Dindarlık Sorununun Tasavvufi Perspektiften Analizi. IV. Uluslararası Din Bilimleri Sempozyumu, (4) 9, 3-5 Mayıs, Alanya.

Çakmaklığlu, M. (2011). İbn A'rabî’ye Göre İbâdetlerin Manevî Boyutları. İstanbul: İnsan Yay.

Çetin, A. (2012). 'Tilâvet' mad. İstanbul: DİA.

Draz, M. A. (1983). İslâm'ın İnsana Verdiği Değer. (trc.: Nurettin Demirel), İstanbul.

Draz, M. A. (2009). Kur'ân Ahlâkı. (çev.: Emrullah Yüksel, Ünver Günay), 4. Baskı, İstanbul.

Ebû Nuaym, A. (t.y.). el-Hilyetu'l-Evliyâ. Beyrut.

Ebû Şâme (1986/1406). Murşidu'l-Vecîz. (thk.: Tayyar Altıkulaç), Ankara.

Ersoy, M. Akif (1980). Safahat. (Tertip: Ömer Rıza Doğrul), 13. Baskı, İstanbul.

Eyüpoğlu, O. \& Cora, M. \& Yıldız, M. (2010). Kur'ân'ın Sosyal Yaptırımsallığı. OMÜİFD, 33, 41-66.

Eyüpoğlu, O. \& Okuyan, M. (2008). "Kur'ân'n Sosyo-Kültürel Koşulları Dikkate Alış1: Ma'rûf Kavramı Örneği”. Ondokuz Mayıs Üniversitesi İlahiyat Fakültesi Dergisi, 26-27, 175213.

Eyüpoğlu, O. \& Usta, N. (2019). “İtaat Kavramının Gerekçeleri Açısından Kur'ân'ın Eleştirel Düşünceye Bakışı". Çukurova Üniversitesi Illahiyat Fakültesi Dergisi, 19(2), 347-378.

Eyüpoğlu, O. \& Yıldız, M. (2016). “Kur’ân’ı Anlamaya Yönelik Literal ve Kültürel Yaklaşımların Sosyal Değişmeye Uyum Açısından İşlevselliği”. MANAS Sosyal Araştırmalar Dergisi, 5(3), 163-198.

Ferâhîdî, H. (1424/2003). Kitâbu'l-Ayn. (thk. ve haz.: Dr. Abdu'l-Hamîd el-Hendâvî), Beyrut. Fîrûzâbâdî, M. (ö. 1415), (1370/1951). Tenvîru'l-Mikbâs min Tefsîri İbn Abbâs, Kahire.

Gazzâli E. (t.y.). E. İhyâu Ulûmi'd-Dîn. Misır.

Gazzâlî, E. (1939). İhyâu Ulûmi'd-Dîn. Kahire.

Gazzâli E.(1982). İhyâu Ulûmi'd-Dîn. Beyrut: Dâru'l-Ma'rife. 
Hadîdî, M. (1978). Menhecu'l-Kur'ân ve's-Sünne fi'l-Alâkâti'l-İnsâniyye, Misır.

Harputî, Abdullatîf (1330). Tenkîhu'l-Kelâm fî Akâidi Ehli'l-İslâm, Ankara: TDV

Hökelekli, H. (1995). "İslâm’in İnsan Görüşü Işı̆ğnda İşçi Hakları". İslâm’da İnsan Modeli ve Hz. Peygamber Örneği, Ankara: TDV Yay.

Hucvîrî, E. (1974). Keşfu'l-Mahcûb. (çev.: Abdulhâdî Kandil), İskenderiyye: Mektebetu'lİskenderiyye.

İsfehânî, R. (t.y.). Müfredât fî Garîbi'l-Kur'ân. (thk. ve dabt.: Muhammed Seyyid Keylânî), Beyrut: Dâru'1-Ma'rife.

İbnu'l-Esîr el-Cezerî, M. (t.y.) Câmiu'l-Usûl li-Ehâdîsisir-Rasûl. (thk.,tah., tlk.: Abdu'l-Kâdir elArnâût), Dârul'l-Fikre.

İbn Fâris b. Zekeriyyâ, E. (1399/1979). Mu'cemu Mekâyîsi'l-Lüğa. (thk.ve dabt.: Abdusselâm Muhammed Hârûn), Misır.

İbn Haldun (1990). Mukaddime (Şark İslâm Klâsikleri). (çev.: Zakir Kadiri Ugan), İstanbul: MEB Yay.,

İbn Hanbel, A.(ö.241/855),(1981). Müsned. İstanbul.

İbn Hambel, A. (t.y.). Müsnedu Amed ibn Hanbel, Müessesetu Kurtuba. Kahire.

İbn Kuteybe, E. (1393/1973). Te’vîlâtu Müşkili’l-Kur'ân. (nşr. Seyyid Ahmed Sakr), Kahire.

İbn Mâce, E. (1992). Sünen. I-11, İstanbul: Çağr1 Yay.

İbn Mâce, (t.y.). Sünenu İbn Mâce. Mektebetu Ebî el-Muâtî, (Kitâbu'z-Zühd).

İbn-i Manzûr, E. (1999/1419). Lisânu't-'Arab. 3. Bask1, Beyrut:

İsmâil Hakkın, E. (t.y.). Tefsîru Rûhi'l-Beyân (Rûhu'l-Beyân fî Tefsîri'l-Kur'ân). Dâru'l-İhyâi'tTurasi'l-Arabî.

İzutsu, T. (1991). Kur'ân'da Dini ve Ahlâki Kavramlar. (trc.: Selahaddin Ayaz), 2.Bask1, İstanbul.

el-Kâfiyecî, M. (1989). Kitâbu't-Teysîr fî Kavâidi İlmi’t-Tefsîr. (Neşre haz.: İsmail Cerrahoğlu), Ankara: AÜİF Yay.

Kalın, İ. (2017). Hoca Ahmet Yesevî, Hüküm ve Hikmet. Bilig, Türk Dünyası Sosyal Bilimler Dergisi, (80).

Karagöz, İ. \& Fikret K. \& İbrahim P. \& Mehmet C. \& Ahmet G. \& İbrahim Ü.(2010). Dinî Kavramlar Sözlüğü. Ankara: DİB Yay.

Karaman, H. \& Mustafa Ç. \& İbrahim K. D. \& Sadrettin G. (2014). Kur'ân Yolu Türkçe Meâli ve Tefsiri. Ankara: DİB Yay.

Kettânî, M. A. (t.y.). et-Terâtîbu'l-İdâriye. Beyrut. 
Kırca, C. (1996). Kur'ân ve İnsan. İstanbul.

Kirmânî, Ş. (1401/1981). Şerhu'l-Buhârî (Buhârînin Sahîh'inde). Beyrut.

Kuşeyrî, A. ( 2001). er-Risâletu'l-Kuşeyriyye. (haz.: Mustafa Zeryug), Beyrut: Mektebetu'lAsriyye.

Kutup, S. (1991). Fî Zilâli’l-Kur'ân. (trc.: Salih Uçan, Vahdettin İnce). İstanbul.

MEB Türkçe Sözlük (1995). İstanbul.

Mesud Efendi (1297). Mirât-ı Mecelle-i Ahkâm-ı Adliyye. İstanbul: Matbaa-i Osmaniye.

Mevlânâ C. (994.) Rubâîler, (çev.: M. Nuri Gençosman). İstanbul: MEB. Yay.

Mu'cemu Elfâzi'l-Kur'ânil-Kerîm (1409/1989). Kahire: Mecmeu'l-Luğa el-Arabiyye.

Muhâsibî, E. (t.y.). er-Riâye li Hukûkıllâh. (nşr., Abdulhalîm Mahmûd), Kahire: Dâru'lMeârif.

Müslim, E. (1992). Sahîhu Müslim. I-III, İstanbul: Çağrı Yayınları.

Müslim (t.y.). el-Câmiu's-Sahîh (Sahîhu Müslim). Beyrut: Dûru'l-Ceyl, (Tahrîmu Zulmi'lMüslimîn).

Nevevî, E. (t.y.). Sahîhu Müslim. (dabt ve tevzih.: S1dkı Muhammed Cemîl el-Attâr), Dâru'1Fikr.

Okuyan, M. (2012). Kısa Sûrelerin Tefsiri. 5. Baskı, İstanbul.

Özel, A. ( 1996). “Gayr-i Müslim” mad. DİA, İstanbul.

Râzî, F. (1401/2000). et-Tefsîru'l-Kebîr. Beyrut: Dâru'l-Kütübi'l-i̇lmiyye.

Rızâ, M. ( 1366/1947). Tefsîru'l-Kur'âni'l-Hakîm (Tefsîru'l-Menâr). Kahire: Dârul'-Menâr.

Sabbağ, Muhammed (1408/1988). Buhûs fî Ulûmi’t-Tefsîr, Beyrut.

Serrâc, E.( 1914). Kitâbu'l-Luma' fi't-Tasavvuf. (thk.: Reynold A. Nicholson), (E.J.Brill), Leiden.

Seyyid Alizâde (1320). Şerhu Şir'ati'l-İslâm. Mahmut Bey Matbaas1.

Siddıkî, M. (1990). İslâm Dünyasında Modernist Düşünce. (trc.: Murat Fırat, Göksel Korkmaz), İstanbul.

Suyûtî, C. (t.y.). el-ítkân fì Ulûmi'l-Kur'ân.

Sülemî, M. (1999). el-Mukaddime fi't-Tasavvuf. (thk.: Yusuf Zeydan), Beyrut: Dâru'1-Cîl.

Sülemî, M. (1421/2001). Tefsîru's-Sulemî (Hakâiku't-Tefsîr). (thk. Seyyid İmrân), Beyrut: Dâru'l-Kütübi'l-İlmiyye.

Sürmeli, M. (2006). Sahabenin Kur'ân Anlayışı. Mavi Yayıncılık. 
İslâmî Bireyin ve Toplumun Oluşmasında Kur'ân'1 Anlama/Yaşama Sorunu: Derûnî ve Yüzeysel

Taberî, E. (1388/1968). Câmiu'l-Beyân an Tevîl-i Ayi'l-Kur'ân. Kahire.

Taberî E. (1992/1412). Câmi'l-Beyân, Beyrut: Dâru'l-Kütübi'l-İlmiyye.

Taftâzânî, S.(1411/1991). Şerhu'l-Akâid. (nşr. M. Adnan Derviş). İstanbul: Mektebetü'lHanîfiyye.

TDK Türkçe Sözlük (1998). Ankara.

İbn Teymiyye, T. (1406), Kitâbu'l-İman. (nşr. Hüseyin Yusuf el-Gazzâlî).

Topçu, N. (2001). Sosyoloji. (haz.: Ezel Everdi, İsmail Kara), İstanbul: Dergâh Yay.

Tusterî, E. (1423). Tefsîru't-Tusterî. Dâru'l-Kütübi'l-İlmiyye, (thk. Muhammed Bâsil Uyûni'sSûdi), Beyrut.

Tirmizî, E.(1992). Sünen. I-V, İstanbul: Çağrı Yay.

Tirmizî (t.y.). Sünenu't-Tirmizî. (thk. Ahmeh Muhammed Şâkir v.dğr.), Beyrut: Dâru İhyâi'tTurasi'l-Arabî.

Uludağ, S. (2002). "Kuşeyrî” mad. İstanbul: TDV İslâm Ansiklopedisi.

Usta, Niyazi \& Eyüpoğlu, Osman (2019). "Sosyolojik Açıdan Din”. Din Sosyolojisi içinde, Editör: Osman Eyüpoğlu, Kırgızistan-Türkiye Manas Üniversitesi Yayınları, 49-62.

Uysal, E. (2005). "'Dindarlığın Ahlâki Temeli Üzerine Bazı Düşünceler". Uludağ Üniversitesi İâhiyat Fakültesi Dergisi, 14(1).

Yazır, E. H. (t.y.). Hak Dini Kur'ân Dili. İstanbul: Eser Kitabevi.

Yümni, S. (1994). İslâm Sosyolojisine Giriş. İstanbul.

Zemahşerî, M. (1424/2003). Tefsîru'l-Keşşâf. (Tashih: Muhammed Abdusselâm Şâhin), 3. Bask1, Beyrut.

Zeydân, A. (1396/1976). el-Vecîz fí Usûli’l-Fıkh. Bağdat. 


\title{
THE PROBLEM OF UNDERSTANDING / LIVING THE QURAN IN THE FORMATION OF THE ISLAMIC INDIVIDUAL AND SOCIETY: PROFOUND AND SUPERFICIAL READING
}

\begin{abstract}
Understanding and internalization of the Qur'an, being the true path guide for humanity, and its shaping human life have always been examined and questioned in terms of its quality. It is possible to find some discussions and many different views about it in Islamic literature. These discussions can be regarded as the way of searching to build a more honorable and prosperous lifestyle in the world, which will enable people to be happy and peaceful in both worlds. In this context, meeting the demands of the Qur'an in a realistic way by adopting it sincerely and in accordance with its purpose and sufficiently learning from the Qur'an by transforming its teachings into a way of life will become possible by understanding its content in a healthy manner. This is an issue related to the capacity of a human to understand the Qur'an. Although Quran addresses all people, what people understand from it is different for the various reasons such as it being a divine and miraculous word, varying in the capacity of the servants, and requiring for his understanding to be specialized. In any case, the sincerity, objectivity and merit that should be present in a person to be able to understand the Quran in a healthy and correct way always exist as a need. The conformity of a person's actions to Quran is also related with the information to be understood from it. Because principles, instructions, suggestions and demands related to the material and spiritual aspects of a person are obtained from it. It is an obligation for believers/Muslim servants to sincerely follow the content of the Quran in their internal and external actions while also considering the meaning and wisdom behind His demands. Quran envisions that there must be signs for its material and spiritual demands in human life to be met in accordance with its content. These can also be expressed as signs that a person experiences the Quran in a suitable and sensible way. In this case, the questions of how these profound and superficial signs correspond to the content of the Quran, how sincerely they are followed in this regard, and the purpose for which they are performed, as well as the necessity of questioning the way of living Islam according to the Quranic criteria comes to mind. In this study, we have attempted to reveal the opinions, comparisons and suggestions on the issues mentioned above by examining the subjects such as what the purpose of the recitation and interpretation of the Qur'an is, how it should be understood and how it should be turned into a lifestyle in accordance with the Qur'an by internalizing its teachings without formalism and superficiality.
\end{abstract}

Keywords: Reading Quran, Interpreting/Explaining the Quran, Internalizing the Quran, Figurism in Living the Quran, the Quran and Life. 